\title{
Ameliorative Effect of Peach Seed Extract on Cyclophosphamide- Induced Cytogenetic and Histological Effects in Mice
}

\author{
Heba Mohamed Salah ${ }^{1,}$, Ezzat Ibrahim Aboul-Ela ${ }^{1}$, Hamdy Hamed Swelim ${ }^{2}$ \\ ${ }^{1}$ Department of Genetic and Cytology, Division of Genetic Engineering and Biotechnology, National Research Centre, Dokki, Gizza, Egypt \\ ${ }^{2}$ Department of Zoology, Faculty of Science, Ain-Shams University, Cairo, Egypt
}

Email address:

hmsalah801@yahoo.com (H. M. Salah), aboul_ela@hotmail.com (E. I. Aboul-Ela), hamdyhamed@msn.com (H. H. Swelim)

${ }^{*}$ Corresponding author

\section{To cite this article:}

Heba Mohamed Salah, Ezzat Ibrahim Aboul-Ela, Hamdy Hamed Swelim. Ameliorative Effect of Peach Seed Extract on CyclophosphamideInduced Cytogenetic and Histological Effects in Mice. International Journal of Genetics and Genomics. Vol. 7, No. 4, 2019 , pp. $136-147$. doi: $10.11648 /$ j.ijgg.20190704.19

Received: November 2, 2019; Accepted: November 22, 2019; Published: December 4, 2019

\begin{abstract}
Cyclophosphamide (CP) is a frequently used drug for its anticancer and immunosuppressive potential. However metabolism of $\mathrm{CP}$ in the body results into toxic chemical compounds (to the liver itself and other non-target vital organs) via oxidative stress, apoptosis induction and finally necrosis. Since there is no escaping of using such medications in spite of their harms this study was designed to access the ability to alleviate the side-effects of CP by using peach seed methanolic extract, due to its nutritional value and therapeutic properties. The peach seed extract has bioactive constituents such as phenols and carotenoids. Methanoloic extract is the most widely used since it offers a high recovery of antioxidant compounds. Mice were divided into five major groups: negative control (untreated group), positive control, was injected (IP) with CP in dose $75 \mathrm{mg} / \mathrm{kg}$ b. wt., Third group received peach seed extract only in a dose of $500 \mathrm{mg} / \mathrm{kg} \mathrm{b.w.,} \mathrm{and} \mathrm{the} \mathrm{fourth} \mathrm{and} \mathrm{fifth} \mathrm{groups} \mathrm{received} \mathrm{two}$ doses of Peach seeds extract 500 and $250 \mathrm{mg} / \mathrm{kg}$ b.wt. after receiving a single dose of CP intraperitoneally. Assessment of the extract was performed using micronucleus test, mitotic chromosomal aberration assay using bone marrow cells, and liver samples were collected for histopathology. Our results demonstrated that CP induced highly significant e genotoxicity, which recorded $9.49 \%$ PE's with micronuclei, comparing to $1.03 \%$ as control, while the induction of chromosomal aberrations was recorded as $67.6 \%$ against $4.4 \%$ as negative control. The histological study on the liver cells recorded noticeable damage with liver cells treated with CP. After peach treatment a significant reduction in CP- induced damage was observed and those groups treated with both extract and CP became nearly similar to the untreated group in all tested parameters. peach methanolic seed extract has the potential to ameliorate the damaging effect of cyclophosphamide at both the genetic and histological levels.
\end{abstract}

Keywords: Cyclophosphamide Genotoxicity, Prunus Persica, Peach Methanolic Seed Extract, Antioxidant, Mice, Micronucleus Assay, Mitotic Chromosomal Aberration Assay, Liver Histopathology

\section{Introduction}

Chemotherapy is one of the most common approaches in cancer treatment, but it is associated with nearly lifethreatening side effects due to its indiscriminate action toward normal cells so it can be extremely difficult for cancer patients to endure [1].

Cyclophosphamide was developed by Brock and Hohorst [2]. It is used as immunosuppressant, chemotherapeutic and anti-cancer agent [3, 4]. It is the most widely used oxazaphosphorines and among the first alkylating agents to be used therapeutically, because phosphoramidase enzymes were thought to be more abundant in tumors compared with normal tissue [5]. It was designed to be cleaved by these enzymes to deliver nitrogen mustard selectively to malignant cells [5]. Alkylating agents act by damaging DNA by forming guanine-guanine and guanine-adenine inter-strand crosslinks so they kill tumor cells by apoptosis [6, 7]. 
The close relation between free radicals and cancer initiated the scientists to focus on the study of their role and development of new therapeutics. Free radicals are formed naturally in the body and play an important role in many normal cellular processes [8, 9], however at high concentrations free radicals can be hazardous to the body and damage all major components of cells, including DNA, proteins, and cell membranes. The damage to cells caused by free radicals, especially the damage to DNA, may play a role in the development of cancer and other hazardous health conditions $[8,9]$. That's why a great interest has been paid for using antioxidants from natural sources to minimize the adverse effects of chemotherapy on normal cells [10].

Waters et al. [11] reported that certain compounds are capable, at nontoxic concentrations, of lowering the rate of spontaneous or induced mutations. These substances are commonly found in plants and can act as natural antimutagens or anticarcinogens, blocking or scavenging free radicals, so they protect against DNA damage [12].

Herbs, medicinal plants and crude drug substances are considered to be a potential source of antioxidants to combat various diseases [13]. Varieties of free radical scavenging antioxidants are found in dietary sources like vegetables, fruits, tea, etc. $[14,15]$. Many phenolics have been reported in stonefruits (including peaches, nectarines, plums, lychees, mangoes, almonds, apricots and cherries) [16, 17]. Many of these phenolics act as antioxidants [18], antimutagenics [19], and anticarcinogenics [20].

In this study we are interested in the Rosaceae member, Prunus persica L. commonly known as "peach", due to its nutritional value and therapeutic properties as consequence of its bioactive constituents such as phenols, carotenoids [21], gallic acid, protocatechuic acid, protocatechu aldehyde, chlorogenic acid, pcoumaric acid and ferulic acid. They exhibit a significant antioxidant activity in in vitro assays [22]. Extensive pharmacological studies established that it possessed also antithrombus [23], anticoagulative, acetylcholine-lowering [18], antihepatic fibrosis [24], and oxygen radical-scavenging activity [25].

Seed extracts of Prunus sp. potentially inhibited the acetylcholine esterase (ACE) in rat hippocampus, and possibly ameliorating cognitions on the Alzheimer disease [18].

Peach extracts in in vivo studies was found to reduce micronuclei induction in bone marrow cells by $43-50 \%$ confirming its protective effect [26]. Peach has compounds that are active against cancer proliferation by blocking cell cycle progression and/ or inducing apoptosis which is directly associated to DNA fragmentation. Selective cytotoxicity against cancer cells while not affecting normal cells is a desired feature of these bioactive compounds [16].

In the present study, we aimed to investigate the bioactivity of the peach Methanolic seed extract prepared by the traditional method to reduce and ameliorate the histological and cytogenetic alterations and DNA damages induced by $\mathrm{CP}$.

\section{Materials and Methods}

\subsection{Chemicals}

All the chemicals used were of commercial origin and of the best grade available. Cyclophosphamide (Endoxan) was produced by Baxter oncology GmbH, Germany, imported by Multi-Pharma, Egypt.

\subsection{Plant Extract}

The Peach seed extract was prepared at the Genetics and Cytology laboratory, National Research Centre (NRC).

Two hundred and fifty grams of squashed air dried seeds (after the removal of the external hard shell) were extracted by cold maceration method for 2 weeks using absolute methanol. The extract was filtered with Whatman No. 1 filter paper. The filtrate was concentrated to dryness in a hot-air oven at $40^{\circ} \mathrm{C}$. The extract was stored in a refrigerator at $4{ }^{\circ} \mathrm{C}$ throughout the duration of this study.

\subsection{Animals}

Male wild-type BALB/C mice (4-6 weeks- old mice; 10 $12 \mathrm{~g}$ for MN Assay; and 6-8 weeks old; 20-25 gm for Chromosomal aberrations test), were obtained from the "Animal House of The National Research Centre (NRC)", Cairo, Egypt. The animals were maintained in a temperature controlled environment at $24^{\circ} \mathrm{C}$ with a $12 \mathrm{~h}$ light/dark cycle, and were provided with drinking water and food ad libitum. Animal experiments were carried out according to the guidelines for the animal care statements of the Ethical Committee, in the NRC. We followed the international guidelines in human care of animals.

\subsection{Experimental Design}

The mice were subdivided into five groups (20mice/group): The first group was considered as negative control (without any treatment), the second group (positive control) was injected intraperitoneally (IP) with CP in dose $75 \mathrm{mg} / \mathrm{kg}$ b. wt. [27], the dose was nearly doubled for more DNA injuries. Third group received peach seed extract in dose $500 \mathrm{mg} / \mathrm{kg}$ b.w. [28], for 5 consecutive days. The fourth and fifth groups received two doses of Peach seeds extract 500 and $250 \mathrm{mg} / \mathrm{kg}$ b.wt. Respectively, which were applied by oral gavage for 5 consecutive days after single dose of CP treatment $(75 \mathrm{mg} / \mathrm{kg}$ b.w). Samples from groups 1, 2 and 3 were collected $24 \mathrm{hrs}$ after last treatment, while samples from groups 4 and 5 were collected 1, 2, 7, and 14days after the last dose.

\subsubsection{Bone Marrow Experiments}

Micronucleus test:

Normochromatic and polychromatic erythrocytes (NCEs and PCEs) were evaluated in the MN test [29]. Micronucleus test was carried out according to [30], to evaluate chromosomal damage in experimental animals. Bone marrow cells were flushed out gently with fetal calf serum (FCS). The cells were collected by centrifugation at $1500 \mathrm{rpm}$ for 10 min at $4^{\circ} \mathrm{C}$. Cell pellet was re-suspended in a drop of FCS 
and smears were prepared onto glass slides, air-dried, fixed by absolute methanol and stained by May-Grünwald/ Giemsa as described by Schmid [30].

The genotoxicity was expressed as the average number of micronucleated PEs (PE withMN) per 100 PEs (\%), (1).

$$
\text { Genotoxicity } \%=\frac{\mathrm{PE} \text { withMN }}{\mathrm{PE}} \times 100
$$

The cytotoxicity was expressed as the ratio of polychromatic erythrocytes to nucleated cells (N), (2).

$$
\text { cytotoxcity } \%=\frac{\mathrm{PE}}{\mathrm{PE}+\mathrm{N}} \times 100
$$

Doses which induced statistically significant increase in the percentage of PEs over that of the control were considered to cause marrow toxicity.

Somatic Chromosomal aberrations

The chromosomes preparation from bone marrow cells were carried out according to the method of Yosida and Amano [31] with some modifications.

Metaphases were stained with Giemsa in phosphate buffer. 100well-spread metaphases were analyzed per animal. Metaphases with different aberrations were recorded.

\subsubsection{Histological Studies}

The liver was removed from mice and transferred into isotonic saline for few seconds to wash excess blood then fixed in fresh $10 \%$ neutral buffered formalin for $24 \mathrm{hrs}$. The tissue was then carefully removed and kept under tap water for 3 hours. Ascending grades of alcohol (70\%, 80\%, 90\%, $95 \%$ and absolute alcohol) were used for dehydration purpose for 30 minutes per grade and then tissues were cleared in clove oil for three days. The tissue was then embedded in paraffin wax. Thin sections of $5-6$ microns were cut, with the help of a digitalized electronic rotary microtome. Then they were deparaffinized in xylene for 10 minutes and hydrated by passing through a descending alcoholic series followed by passing through distilled water and staining was performed using Harris Haematoxylin solution and counter - staining was performed with eosin stain, dehydrated in ethanol, cleared in Xylene, mounted in DPX, investigated under light microscope (Leica DM750), and images were taken with digital mounted camera (EOS $700 \mathrm{D})$ at 160,320 and 640 power magnifications.

\subsection{Statistical Analysis}

All data from control and experimental animals in micronucleus test and chromosomal aberration assay were calculated using the student t- test in order to evaluate the significancy effects of the tested compounds.

\section{Results}

\subsection{Cytogenetic Study}

\subsubsection{Micronucleus Assay}

The bone marrow cells of animals were evaluated for DNA damage after treatment with the test compounds. Aneugenic/ clastogenic damage was examined by the analysis of formation of micronuclei in the PE of bone marrow of. Table 1 , represents the results of Micronucleus assay (MN) as cytotoxicity and genotoxicity markers, it demonstrated that, cyclophosphamide (CP) recorded high significant effect of toxicity which reached $54.5 \%$, compared to the control $(9.7 \%)$, while group treated with peach extract recorded $18.00 \%$. Both high and low doses of peach taken with CP remarkably showed decrease in toxicity with time. Percentage of PE decreased to be non-significant with the high dose after 1 week, while the low dose reached to nonsignificant after 2 weeks.

The MN genotoxicity results indicated a significant increase $(p<0.05)$ in the mean percentages of $\mathrm{MN}$ in CPtreated group compared to control. The treatment of peach extract with $\mathrm{CP}$ groups led to a decreasing of the genotoxicity referred to CP with time depending as shown in table 2 .

\subsubsection{Chromosomal Aberration Assay}

Table 3 and Figure 1 pointed up that $\mathrm{CP}$ induced different types of structural and numerical Chromosomal aberrations (CAs) in mouse bone marrow cells. The percentage of CAs reached $67.6 \%$ after the induction of $\mathrm{CP}$. Peach high dose alone recorded $7.6 \%$, while peach extract with $\mathrm{CP}$ recorded significant values after 24, 48 and one week with the high dose recorded 21.4, 14 and 10.6 respectively. The same results were obtained with the low dose of peach extract (23.2, 15.2 and 11.8), The two used concentrations of peach extract reach nearly the control value after two weeks of treatment.

The main types of chromosomal aberrations were centromeric attenuation, endomitosis and fragmentation clearly observed with $\mathrm{CP}$ treatment. These three types of aberrations were recorded with high percentage with $\mathrm{CP}$ treatment, while with the high and low doses of peach extract treatments, these types strongly retreated to a moderate levels and down to the least percentage after 2 weeks of treatment.

Table 1. Percentage of polychromatic erythrocytes in mouse bone marrow cells after single cyclophosphamide treatment and high and low doses of peach

\begin{tabular}{|c|c|c|c|c|c|}
\hline Treatment & Time period & Mice No. & Counted nucleatd cells + PE No. & PE & PE \% \pm S.E. \\
\hline Control & 0 & 4 & 8000 & 776 & $9.70 \pm 0.15$ \\
\hline Cyclophosphamide & $24 \mathrm{hrs}$ & 4 & 8000 & 4360 & $54.50 \pm 0.34 * *$ \\
\hline Peach (high dose) & $24 \mathrm{hrs}$ & 4 & 8000 & 2345 & $18.00 \pm 0.67 * *$ \\
\hline \multirow{3}{*}{ Peach (high) + CP. } & $48 \mathrm{hrs}$ & 4 & 8000 & 1024 & $12.80 \pm 1.34 *$ \\
\hline & 1 week & 4 & 8000 & 848 & $10.6 \pm 0.67$ \\
\hline & 2 weeks & 4 & 8000 & 792 & $9.9 \pm 0.34$ \\
\hline
\end{tabular}
seeds extract. 


\begin{tabular}{llllll}
\hline Treatment & Time period & Mice No. & Counted nucleatd cells + PE No. & PE & PE \% \pm S.E. \\
\hline & $24 \mathrm{hrs}$ & 4 & 8000 & 1046 & $13.07 \pm 0.82 *$ \\
Peach (low) + CP. & $48 \mathrm{hrs}$ & 4 & 8000 & 1119 & $13.98 \pm 0.78^{*}$ \\
& 1 week & 4 & 8000 & 944 & $11.8 \pm 1.34 *$ \\
& 2 weeks & 4 & 8000 & 808 & $10.1 \pm 1.67$ \\
\hline
\end{tabular}

* Significant at $(\mathrm{P}<0.05) * *$ Significant at $(\mathrm{P}<0.01)$.

Table 2. Percentage of polychromatic erythrocytes with micronuclei in mouse bone marrow cells after single cyclophosphamide treatment and high and low doses of peach seeds extract.

\begin{tabular}{llllll}
\hline Treatment & Time period & Mice No. & PENo. & Micronucleated PE & PE's with micronuclei \% \pm S.E. \\
\hline Control & 0 & 4 & 776 & 8 & $1.03 \pm 0.20$ \\
Cyclophosphamide & $24 \mathrm{hrs}$ & 4 & 4360 & 414 & $9.49 \pm 1.67^{* *}$ \\
Peach (high dose) & $24 \mathrm{hrs}$ & 4 & 2345 & 122 & $5.20 \pm 0.34^{* *}$ \\
& $24 \mathrm{hrs}$ & 4 & 1007 & 41 & $4.07 \pm 1.78^{* *}$ \\
& $48 \mathrm{hrs}$ & 4 & 1024 & 37 & $3.61 \pm 0.78^{*}$ \\
Peach (high) + CP. & 1 week & 4 & 848 & 18 & $2.12 \pm 1.78^{*}$ \\
& 2 weeks & 4 & 792 & 14 & $1.77 \pm 1.78$ \\
& $24 \mathrm{hrs}$ & 4 & 1046 & 53 & $5.07 \pm 0.89^{* *}$ \\
Peach (low) + CP. & $48 \mathrm{hrs}$ & 4 & 1119 & 45 & $4.02 \pm 0.89^{* *}$ \\
& 1 week & 4 & 944 & 28 & $2.97 \pm 0.89^{*}$ \\
\hline
\end{tabular}

* Significant at $(\mathrm{P}<0.05) * *$ Significant at $(\mathrm{P}<0.01)$.

Table 3. Mean percentage of metaphases with different types of chromosomal aberrations in mouse bone marrow cells treated with single dose of cyclophosphamide (75 $\mathrm{mg} / \mathrm{kg}$ ) and two doses of peach seeds extract (500, and $250 \mathrm{mg} / \mathrm{kg} \mathrm{b.} \mathrm{w.).}$

\begin{tabular}{|c|c|c|c|c|c|c|c|c|c|c|c|}
\hline \multirow[b]{2}{*}{ Treatment } & \multirow{2}{*}{$\begin{array}{l}\text { Time } \\
\text { period }\end{array}$} & \multirow{2}{*}{$\begin{array}{l}\text { Metaph. } \\
\text { With C. A. } \\
\text { No. }\end{array}$} & \multicolumn{8}{|c|}{ Types of aberrations } & \multirow{2}{*}{$\begin{array}{l}\text { Metaph. With } \\
\text { chr. Aberr. } \\
\% \pm \text { S.E. }\end{array}$} \\
\hline & & & $\begin{array}{l}\text { Cht. } \\
\text { Gap }\end{array}$ & $\begin{array}{l}\text { Chr. } \\
\text { Gap }\end{array}$ & Del. & $\begin{array}{l}\text { Chr. } \\
\text { break }\end{array}$ & Frag. & $\begin{array}{l}\text { Cen. } \\
\text { Aten } \\
\end{array}$ & Endo Mito & Fragmentation & \\
\hline \multirow{3}{*}{$\begin{array}{l}\text { Control } \\
\text { CP. } \\
\text { Peach (high } \\
\text { dose) }\end{array}$} & 0 & 22 & 9 & 2 & 3 & - & 8 & - & - & - & $4.4 \pm 0.67$ \\
\hline & $24 \mathrm{hrs}$ & 338 & 24 & 19 & 22 & 9 & 43 & 35 & 51 & 135 & $67.6 \pm 1.56 * *$ \\
\hline & $24 \mathrm{hrs}$ & 38 & 15 & 7 & 6 & 6 & 4 & - & - & - & $7.6 \pm 0.34 *$ \\
\hline \multirow{3}{*}{$\begin{array}{l}\text { Peach } \\
(\text { high })+ \\
\text { CP. }\end{array}$} & $24 \mathrm{hrs}$ & 107 & 15 & 12 & 14 & 7 & 10 & 16 & 13 & 20 & $21.4 \pm 1.34 * *$ \\
\hline & 1 week & 53 & 12 & 9 & 12 & 5 & 6 & 4 & 1 & 4 & $10.6 \pm 0.67 * *$ \\
\hline & 2 weeks & 32 & 11 & 4 & 8 & 4 & 2 & 2 & - & 1 & $6.4 \pm 1.45$ \\
\hline \multirow{4}{*}{$\begin{array}{l}\text { Peach (low) } \\
+\mathrm{CP}\end{array}$} & $24 \mathrm{hrs}$ & 116 & 16 & 12 & 16 & 7 & 12 & 17 & 14 & 22 & $23.2 \pm 0.67 * *$ \\
\hline & $48 \mathrm{hrs}$ & 76 & 13 & 8 & 14 & 6 & 4 & 7 & 8 & 16 & $15.2 \pm 1.67 * *$ \\
\hline & 1 week & 59 & 12 & 9 & 12 & 5 & 6 & 4 & 3 & 8 & $11.8 \pm 0.34 * *$ \\
\hline & 2 weeks & 37 & 11 & 4 & 8 & 4 & 4 & 2 & 1 & 3 & $7.4 \pm 0.78$ \\
\hline
\end{tabular}

*Significant at $(\mathrm{P}<0.05) * *$ Significant at $(\mathrm{P}<0.01)$ total investigated metaphases No. /Group is 500.

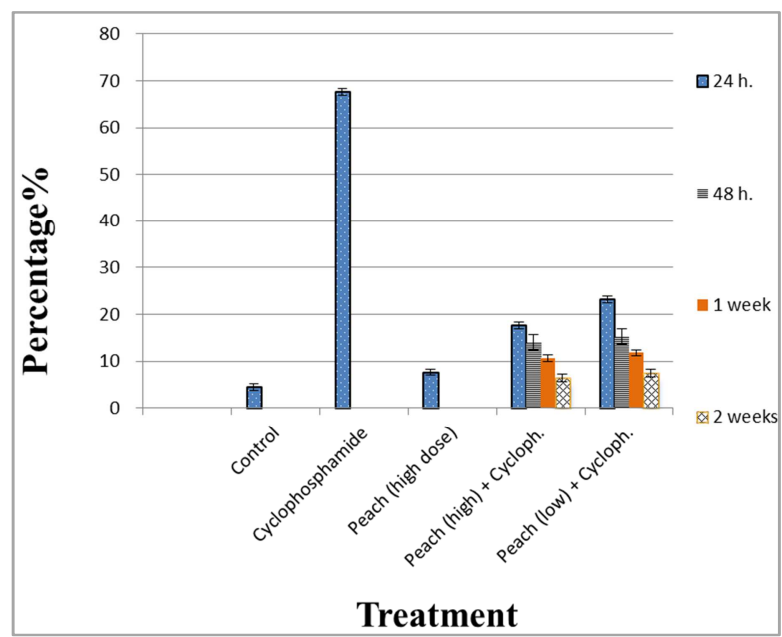

Figure 1. Chromosomal aberrations percentage of mouse bone marrow cells of control, treated CP, high dose peach extract, and two doses of peach seeds extracts for different time periods.

\subsection{Histological Study}

\subsubsection{Control Group}

Microscopical investigation of liver sections of control mice as represented in figure 2, showed normal histological pattern. All hepatocytes were intact arranged in strands inbetween which lie the sinusoids lined by their endothelial cells beside and Kupffer cells bulged towards sinusoidal lumen. Most of the nuclei are rounded with prominent nucleoli which sometimes are numerous and cytoplasm appears filled with flocculent basophilic ergastoplasm in eosinophilic background. Large number of hepatocytes are binucleated indicating regenerative capability. In portal areas the hepatic portal vein and bile ducts are of normal caliber.

\subsubsection{Cyclophosphamide Group}

Examination of liver sections of mice injected with CP (75 $\mathrm{mg} / \mathrm{kg} \mathrm{b}$. w.) as shown in figure 2 , showed portal areas with congested portal veins, hyperplasia of bile duct, irregular dilated blood sinusoids with active Kupffer cells. Other 
regions showed necrotic cells with condensed pyknotic nuclei, sometimes devoid of their nuclei, and microvesicular fatty degeneration of hepatocytes, Focal infiltration of leucocytes and detachment of parenchyma, and fibroplasia in portal area around portal veins were also observed.
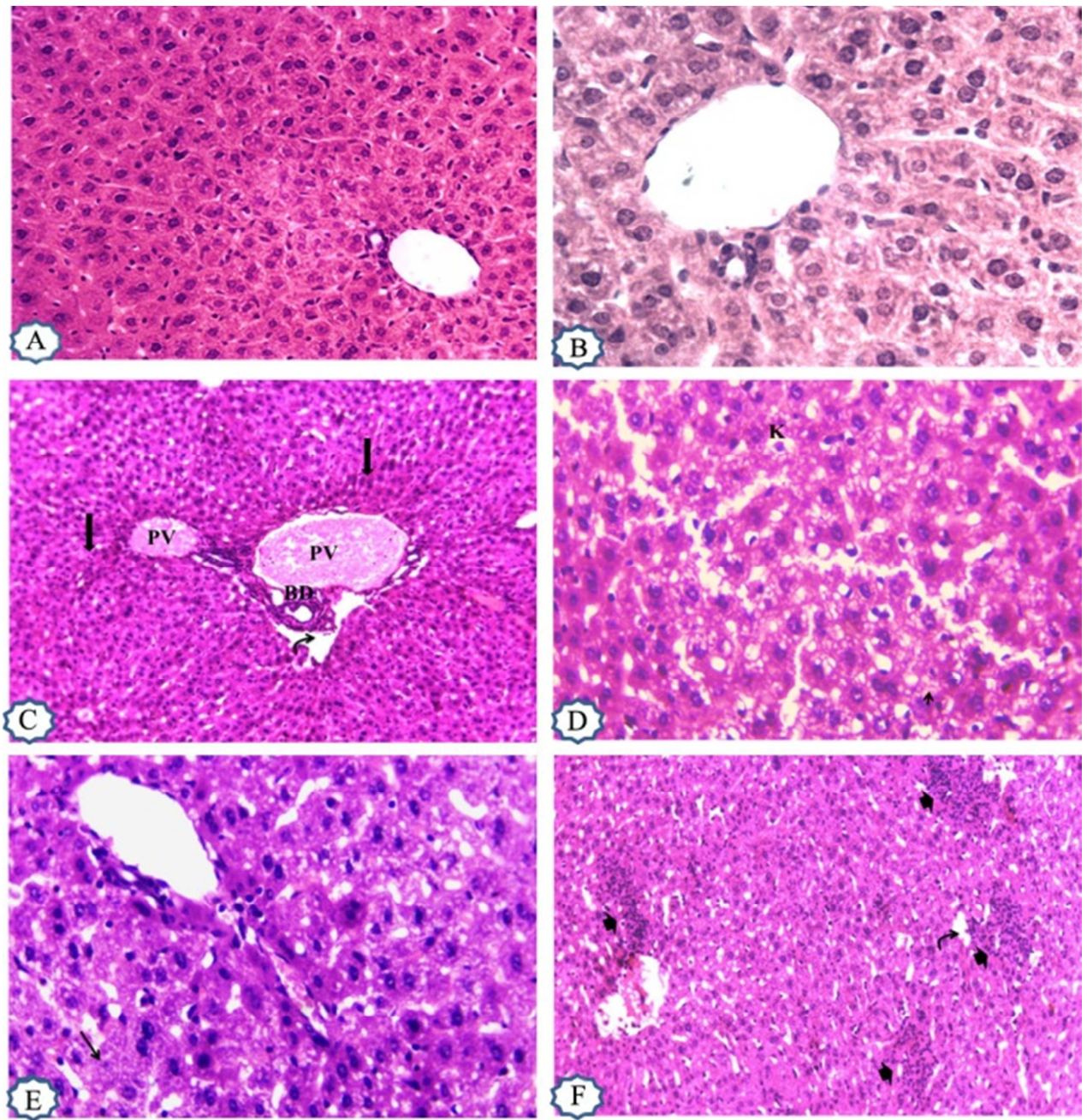

Figure 2. Haematoxylin and Eosin stained liver tissue, 320X, 640X Negative control and $75 \mathrm{mg} C P$ treated group. A, B: Negative control; liver sections of mice showing the normal histological structure of hepatocytes, sinusoidal space, and portal vein. $C, D, E$, and F after 24hrs of CP treatment: showed portal areas with congested portal vein (PV), hyperplasia of bile duct (BD), irregular dilated blood sinusoids with active Kupffer cells (K). Other regions showed necrotic cells with condensed pyknotic nuclei, sometimes devoid of their nuclei (arrow), and microvesicular fatty degeneration of hepatocytes (arrow head), Focal infiltration of leucocytes (thick arrow head) and detachment of parenchyma (curved arrow), and fibroplasia in portal area around portal veins were also observed (thick arrow).

\subsubsection{Group Treated with Peach Extract Only}

Histological examination of liver sections of this group showed prominent increase in the number and activity of Kupffer cells and slight dilation of blood sinusoids after $24 \mathrm{hrs}$ from last treatment (figure 3), occasionally focal leucocytic infiltration was noticed in some portal area.

\subsubsection{Group Four (CP + High Dose of Peach Extract)}

Group treated with single dose of cyclophosphamide followed by five consecutive high doses of peach extract:

Histological investigation of liver sections from animals examined $24 \mathrm{hrs}$ after last high dose of peach extract revealed that minor histological changes were observed and represented in the form of slight congestion of central and portal veins (figure 3 ).

After $48 \mathrm{hrs}$ no further changes could be observed, while after 7 days the presence of inflammatory leucocytes were occasionally observed especially in portal area (figure 3 ).

Fourteen days after the last high dose of peach extract no further changes were noticed but the congestion and inflammation are still existing (figure 3).

\subsubsection{Group Five (CP + Low Dose of Peach Extract)}

Group treated with single dose of cyclophosphamide followed by five consecutive low doses of peach extract:

Animals examined $24 \mathrm{hrs}$ after last dose of peach extract showed slight leucocytic infiltration and congestion of portal veins associated with the increase in the number of active Kupffer cells (figure 4).

Examination after $48 \mathrm{hrs}$ from the last dose of peach extract showed marked increase of active Kupffer cells and slight dilation of blood sinusoids (figure 4). 
After seven days from the last dose of peach extract prominent increase of lipid content in hepatocytes was noticed and that was expressed in the form of focal micro and macro vesicular fatty degeneration which give the liver tissue the foamy appearance, Also the number of active Kupffer
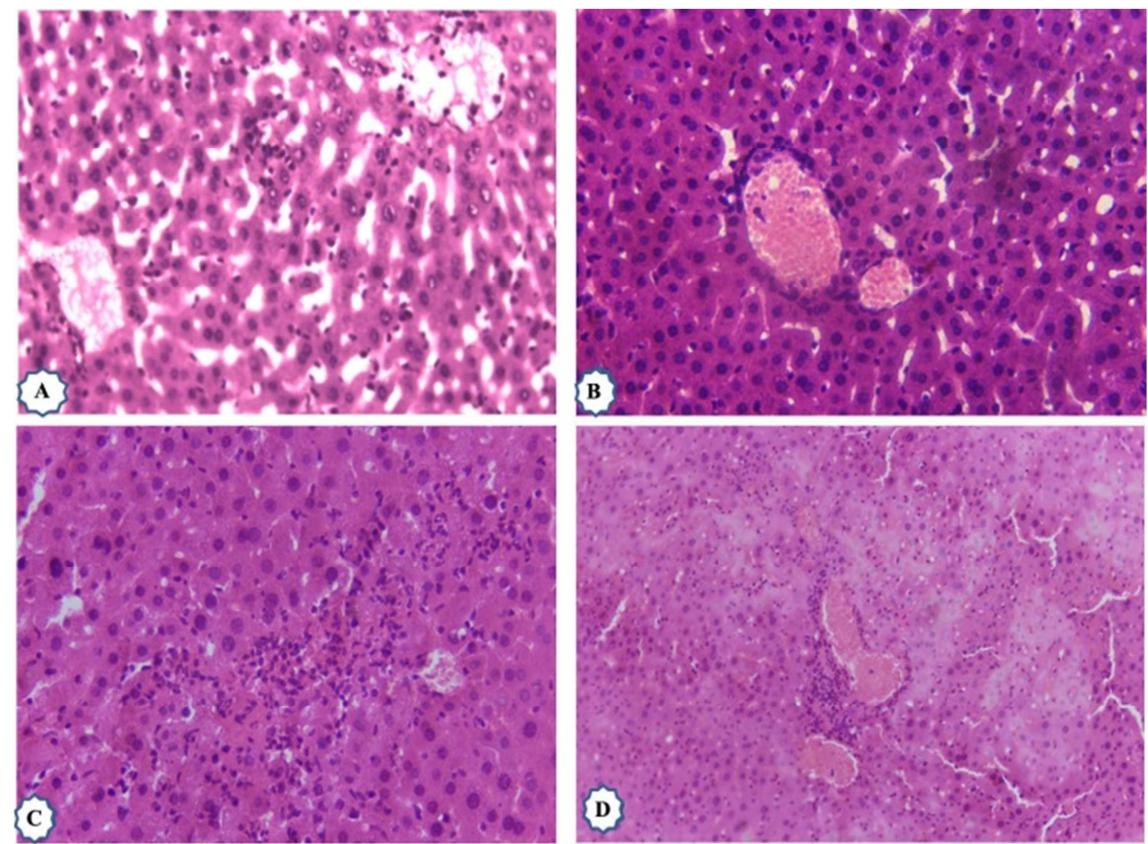

Figure 3. Haematoxylin and Eosin stained liver tissue, 320X, 640X. (A) 500mg peach treated group, 24hrs after treatment: prominent increase in the number and activity of Kupffer cells and slight dilation of blood sinusoids, leucocytes infiltration. Group received $75 \mathrm{mg}$ (ip) CP then 500mg peach: (B) $24 \mathrm{hrs}$ after last treatment: Normal histological pattern except for slight congestion of portal vein. (C) 7 days after last treatment: normal hepatocyte, normal sinusoidal spaces with mild leucocytes infiltration. (D) 14 days after last treatment: normal pattern of portal area with slight changes represented in focal leucocytes infiltration and congestion of portal veins.
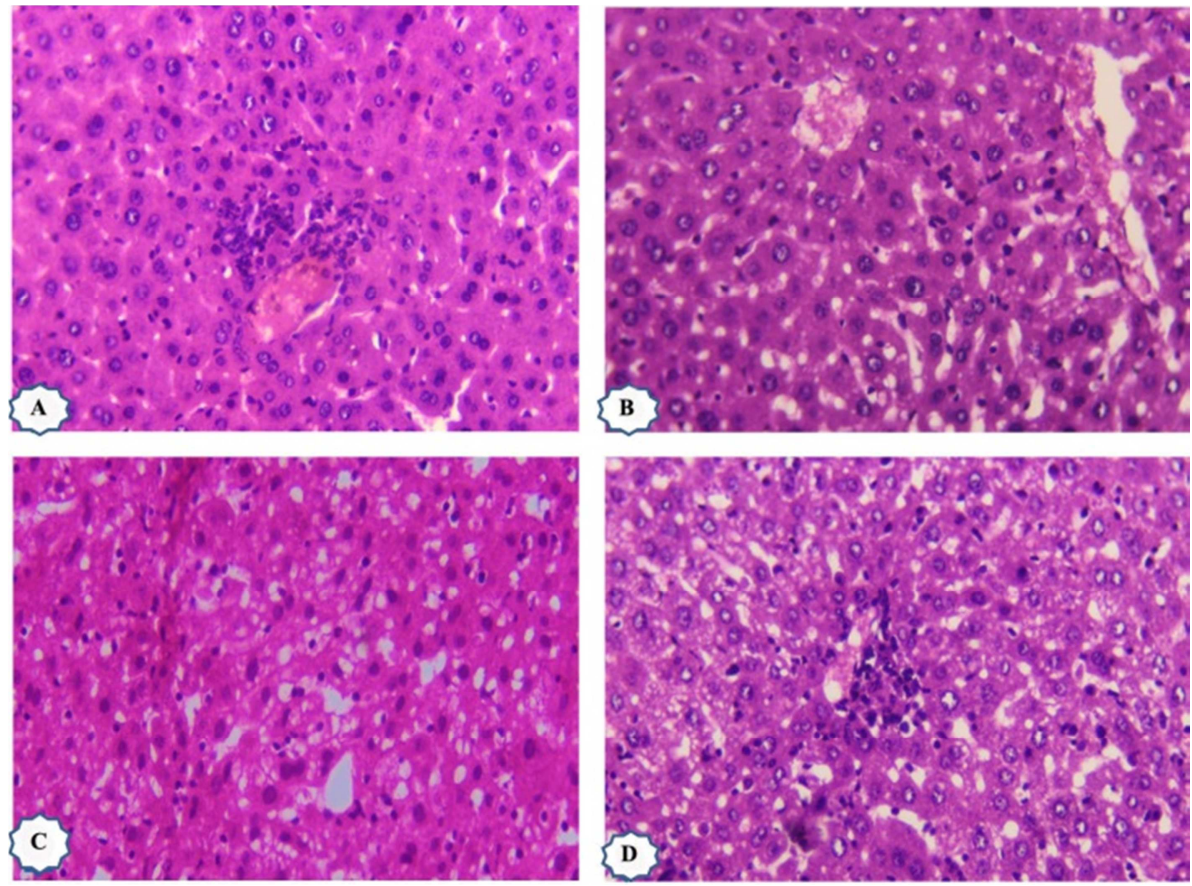

Figure 4. Haematoxylin and Eosin stained liver tissue, 640X. Group received $75 \mathrm{mg}$ (ip) CP then $250 \mathrm{mg}$ peach: (A) 24hrs after last treatment: portal area shows focal leucocytes and Kupffer cells infiltration and congestion of portal vein. (B) 48hrs after last treatment: dilation of blood sinusoids, increasing in the number of active Kupffer cells in the tissue. (C) 7 days after last treatment: dilation of blood sinusoids, increasing in the number of active Kupffer cells in the tissue, the foamy appearance of hepatocyte cytoplasm is due to microvesicular and macrovesicular fatty degeneration. (D) 14 days after last treatment: dilation of blood sinusoids, increasing in the number of active Kupfer cells in the tissue, the foamy appearance of hepatocyte cytoplasm is due to microvesicular and macrovesicular fatty degeneration. 


\section{Discussion}

Our target in the present study is to explore the bioactivity of the peach methanolic seed extract on the cyclophosphamide- induced cytogenetic disorders and pathology of liver.

$\mathrm{CP}$ is used as an antineoplastic agent for treatment of various cancers. This chemotherapeutic agent has several clinical side effects which minimized its clinical applications [32]. Several studies have demonstrated that these side effects may be attributable to interruption of redox stability of tissues which result in oxidative stress and production of free radicals and reactive oxygen species [33, 34].

The most lethal effects of the CP free radicals in vivo are genotoxic activities, including DNA mutilation, chromosomal abnormalities, sister chromatid exchanges, and gene mutations, which lead to a number of pathological conditions, including cancer [35]. Several studies have reported that intraperitoneal administration of $\mathrm{CP}$ can lead to DNA damage, chromosomal abnormalities and sister chromatid exchanges, as well as a reduction in mitotic index [36]. This agrees with our finding that, CP induced different types of structural and numerical chromosomal aberrations (CAs) in mouse bone marrow cells. The percentage of CAs reached $67.6 \%$, mainly were fragmentation, centromeric attenuation, and endomitosis, which were clearly observed with CP treatment.

Dkhil et al. [37] reported that centromeric attenuation is an expression of non-specific cytotoxicity. The same phenomenon was described by Dolara et al. [38] as a chromatid separation under the name "nonsynchronous centromeric separation" and concluded that the disturbances of the spindle filaments are likely to be the cause of the disruption of the centromeric apparatus during mitosis, which manifests itself as a chromatid separation.

Dkhil, Tohamy and Gabry [37] stated that disturbance of the spindle apparatus is a suggested mechanism for polyploidy. That was confirmed by previous studies $[39,40]$ in which was mentioned that, centromeric attenuation, splitting of the centromere without mitosis, may be an early stage of endomitosis, which leads eventually to polyploidy.

Our results were parallel with the finding of Goldberg et al. [41] which stated that, CP at doses of $0-50 \mathrm{mg} / \mathrm{kg}$, induced a larger increase in micronuclear frequency in the bone marrow, also Aboul-Ela and Omara [27], reported that CP as colon and hepatic cancer inducer and has clastogenic effect.

The cyclophosphamide effect is pronounced when liver microsomal P450 oxidases bioconvert $\mathrm{CP}$ into various metabolites, which were unexpectedly, found very harmful to the liver itself; and various body tissues. The main metabolite and the most harmful is acrolein [42, 43]. Acrolein is responsible for producing free radicals through interaction with the body's antioxidant defense system. The free radicals are highly reactive and cause oxidation of various enzymes [44]. Acrolein leads to cellular damage after binding with the glutathione (GSH) and reduction of its level in the cell [45].
As a result, acrolein impairs the GSH dependent antioxidant system and amplifies free radical production [46]. Murata, Suzuki, Midorikawa, Oikawa and Kawanishi [36] reported that $\mathrm{CP}$ induces DNA damage through an oxidative process, which is caused by the generation of $\mathrm{H}_{2} \mathrm{O}_{2}$. That makes drugs (such as cyclophosphamide, carbon tetrachloride, nitrosamines and..... etc.), that are used nowadays to be described as hepatotoxic agents. This is due to their damaging effects on liver tissue by giving rise to intermediary reactive oxygen species that, after exhausting liver antioxidant store, lead to liver damage. Furthermore, malignancies might result as a consequence to liver's higher regeneration capacity, especially in advanced conditions of fibrosis and cirrhosis. Hindering or minimizing these damaging effects on the liver is a goal for research combating primary liver damage or damage secondary to drugs and chemotherapeutics. Consequently, proposing hepatoprotective strategies to accompany such hepatotoxic, but necessary, medications is very important [47].

Liver histopathological results revealed that CP causes damage to the liver and colon. Liver damage represented in hepatocytes vacuolation, inflammatory cell infiltration, bridging necrosis with early fibrosis between portal tract and central veins, basophilic cells with large polymorphic and hyperchromatic with deeply stained shrunken pyknosis, dysplastic hepatocytes, and apoptotic cells [27].

Further studies confirm typical liver damage associated with CP administration [48-50]. Moreover, this was confirmed by other recent histopathological studies [47, 5153], in which major $\mathrm{CP}$ induced histopathological alterations in liver tissue were periportal inflammation, inflammatory cells infiltration, hemorrhage, congestion of blood vessels, hepatocyte necrosis around the central veins, pyknosis of nuclei, cellular disintegration, and distortion.

These findings agree with our histopathological results in this study in which CP main damage to liver was represented in hydropic and fatty degeneration, focal area inflammation, focal apoptosis, and fibroplasia in portal area around portal veins as shown.

Although it is not classified as a direct carcinogen by the department of health and human services (DHHS), centers for disease control and prevention (CDC), USA (https://www.atsdr.cdc.gov/toxfaqs/tf.asp?id=555\&tid=102), occurrence of carcinogenesis after $\mathrm{CP}$ administration is possible [43, 54], especially in organs with higher regeneration rate as liver. In fact, few secondary malignancies were already reported following $\mathrm{CP}$ administration $[55,56]$.

Consumption of fruits and vegetables reduce risk of cancer for many human organs [57] because of their antioxidant properties. The antioxidant compounds found in them are capable to neutralize free radicals, and prevent diseases such as cancer [58].

The bioactive compounds found in P. persica L., are mainly gallic acid, protocatechuic acid, protocatechu aldehyde, chlorogenic acid, pcoumaric acid and ferulic acid. 
They exhibit a significant antioxidant activity in in vitro assays [22]. Peaches and apricots contain significant quantities of components with various health benefits such as phenolics and carotenoids [59].

Many phenolics have been reported in stone fruits including peaches, nectarines, plums, lychees, mangoes, almonds, apricots and cherries. These phenolics are such as anthocyanins, hydroxycinnamates, flavan 3-ols and flavonols, predominantly chlorogenic acid, neo-chlorogenic acid, catechin, epicatechin, and quercetin 3-rutinoside [16]. Many of these phenolics act as antioxidants [18], antimutagenics [19], and anticarcinogenics [20].

Several research papers reported the analysis of bioactive constituents of $P$. persica using different solvents in the extraction procedure. Among them methanol was the most widely used since it offers a high recovery of antioxidant compounds $[17,21]$.

Peach extract in in vivo studies reduced micronuclei induction in bone marrow cells by $43-50 \%$ confirming its protective effect [26]. Average protective potencies against induction of micronuclei were detected with oranges and peaches against CP [60]. Those studies endorse our results in which peach extracts treatment reduced the cytotoxicity and genotoxicity induced with CP remarkably. Mitotic chromosomal aberration results in the present study also, confirm the protective effect of peaches, in which the percentage of $\mathrm{CP}$ - induced chromosomal damage reduced to be insignificant with time as shown.

The plant families (i.e. Lamiaceae, Fabaceae, Apiaceae, Rosaceae, Asteraceae, Solanaceae, and Brassicaceae) have the largest contribution to development of treatments against liver and spleen diseases [61].

The extracts of Fargaria ananassa, Prunus armeniaca and Prunus persica fruits exert a good in vitro and in vivo antioxidant activity. The treatment of animals with these extracts resulted in a reduction in the lipid peroxidation in liver tissue of rats. So their consumption can reduce the risk of several diseases associated with oxidative stress such as cancer, diabetes, aging and cardiovascular diseases [62].

Results from the animal study demonstrated that peach phenolics inhibited tumor growth and protected against angiogenesis and metastasis [63]. The peach phenolics were found to deregulate breast cancer invasion and metastasis [64].

The intragastrointestinal delivery of the plant material is relevant because it resembles the intake of phenolics through a diet rich in fruits and vegetables or dietary supplements made from plant extracts, especially those plant foods that may contain a phenolic profile similar to stone fruits [17]. Indeed, the bioactive compounds can pass through the intestinal barrier and effectively reach the tumors [65].

Plant extract of the flower of $P$. persica affords substantial protection against photocarcinogenesis in a mouse model [66].

Further studies of peaches protective effect against chemical mutagens such as cisplatin showed that, the oral administration of pericarp extract of P. Persica (PPE) (500 $\mathrm{mg} / \mathrm{kg}$, b.w.) showed a significant protection against cisplatin-induced acute nephrotoxicity and hepatotoxicity. Also reduced the oxidative stress induced by a single administration of cisplatin (45 mg/kg, i.p.) over a 16-hour period in mice. That suggest a possibility for the utilization of PPE as a beneficial supplement during cisplatin chemotherapy [67].

Tao-Hong-Si-Wu decoction (THSWD) is a traditional Chinese herbal medicine which composed of (Prunus persica (L.), Ligusticum chuanxiong Hort., Carthamus tinctorius L., Rehmannia glutinosa Libosch, Angelica sinensis (Oliv.) Diels, and Paeonia lactiflora Pall Batsch), decreased hepatic necroinflammatory disease and fibrosis in a $\mathrm{CCl}_{4}$-induced liver injury model that was supported with histopathological examination [68].

Histopathological study of improved prescription of Taohechengqi-tang which consists of (Radix paeoniae rubra $100 \mathrm{~g}$, Semen persicae (dried seed of prunus persica) $50 \mathrm{~g}$, Flos carthami 50 g, Hirudo 15 g, Scorpio 10 g, Natrii sulfas $10 \mathrm{~g}$, and Radix et rhizoma rhei palmate $30 \mathrm{~g}$ ) demonstrated its effect that attenuates inflammation in acute liver failure induced with D-galactosamine [69].

Histopathological examination indicated that methyl amygdalinate which is an active aromatic glucoside isolated from P. persica markedly ameliorated neurodegeneration in the hippocampus in mice [70].

These studies are consistent with our histopathological results showing that, peach seeds extract attenuates $\mathrm{CP}$ induced hepatotoxicity.

Despite of peaches protective effect against the CPinduced damage, the treatment of peach seed extract only showed significant toxicity compared to untreated group represented in high percentage of chromosomal aberrations and cytotoxicity. This might relate to the toxic component of peach seeds that is known as amygdalin. It is a source of hydrogen cyanide, which can induce life-threaten respiratory disorders however, it is usually present in levels too small to cause any harm [71].

\section{Conclusion}

Peach methanolic seed extract has been shown to ameliorate the damaging effect of cyclophosphamide at both the genetic and histopathological levels.

\section{References}

[1] BERTOLINI, F., PAUL, S., MANCUSO, P., MONESTIROLI, S., GOBBI, A., SHAKED, Y., and KERBEL, R. S., 2003. Maximum tolerable dose and low-dose metronomic chemotherapy have opposite effects on the mobilization and viability of circulating endothelial progenitor cells. Cancer $\begin{array}{llll}\text { Research 63, (15), 4342-4346. } & \text { 63 }\end{array}$ https://www.ncbi.nlm.nih.gov/pubmed/12907602.

[2] BROCK, N. and HOHORST, H. J., 1967. Metabolism of cyclophosphamide. Cancer 20, (5), 900-904. https://www.ncbi.nlm.nih.gov/pubmed/6024299. 
[3] GULIA, S. and KUMAR KATARIA, S., 2017. Histological alterations induced due to malathion and cyclophosphamide exposure in mice 5 . https://www.researchgate.net/publication/320977844_Histolog ical alterations induced due to malathion and cyclophosph amide_exposure_in_mice.

[4] ABDELLA, E. M., 2012. Short-term comparative study of the cyclophosphamide genotoxicity administered free and liposome-encapsulated in mice. Iranian journal of cancer prevention $\quad 5, \quad$ (2), 51. https://www.ncbi.nlm.nih.gov/pmc/articles/PMC4299619/.

[5] BROCK, N., 1989. Oxazaphosphorine cytostatics: pastpresent-future: seventh cain memorial award lecture. Cancer Research 49, (1), 1-7. https://cancerres.aacrjournals.org/content/49/1/1.article-info.

[6] HICKMAN, J. A., 1992. Apoptosis induced by anticancer drugs. Cancer Metastasis Rev 11, (2), 121-139. DOI https://doi.org/10.1007/BF00048059.

[7] O'CONNOR, P. M., WASSERMANN, K., SARANG, M., MAGRATH, I., BOHR, V. A., and KOHN, K. W., 1991. Relationship between DNA cross-links, cell cycle, and apoptosis in Burkitt's lymphoma cell lines differing in sensitivity to nitrogen mustard. Cancer Research 51, (24), 6550-6557. https://www.ncbi.nlm.nih.gov/pubmed/1742728

[8] DIPLOCK, A., CHARULEUX, J.-L., CROZIER-WILli, G., KOK, F., RICE-EVANS, C., ROBERFROID, M., STAHL, W., and VINA-RIBES, J., 1998. Functional food science and defence against reactive oxidative species. British Journal of Nutrition $80, \quad$ (S1), $\quad$ S77-S112. https://doi.org/10.1079/BJN19980106.

[9] VALKO, M., LEIBFRITZ, D., MONCOL, J., CRONIN, M., MAZUR, M., and TELSER, J., 2007. Free radicals and antioxidants in normal physiological functions and human disease. Int. J. Biochem. Cell. Biol. DOI 10.1016/j.biocel.2006.07.001.

[10] PRATHEESHKUMAR, P. and KUTTAN, G., 2010. Ameliorative action of Vernonia cinerea L. on cyclophosphamide-induced immunosuppression and oxidative stress in mice. Inflammopharmacology 18, (4), 197-207. DOI 10.1007/s10787-010-0042-8.

[11] WATERS, M. D., STACK, H. F., JACKSON, M. A., BROCKMAN, H. E., and DE FLORA, S., 1996. Activity profiles of antimutagens: in vitro and in vivo data. Mutation Research/Fundamental and Molecular Mechanisms of $\begin{array}{llll}\text { Mutagenesis } & 350, & \text { (1), 109-129. DOI }\end{array}$ https://doi.org/10.1016/0027-5107(95)00097-6.

[12] KAUR, S., ARORA, S., KAUR, K., and KUMAR, S., 2002. The in vitro antimutagenic activity of Triphala - an Indian herbal drug. Food and Chemical Toxicology 40, (4), 527-534. DOI https://doi.org/10.1016/S02786915(01)00101-6.

[13] NOH, J.-R., KIM, Y.-H., GANG, G.-T., HWANG, J.-H., KIM, S.-K., RYU, S.-Y., KIM, Y.-S., LEE, H.-S., and LEE, C.-H., 2011. Hepatoprotective effect of Platycodon grandiflorum against chronic ethanol-induced oxidative stress in C57BL/6 mice. Annals of Nutrition and Metabolism 58, (3), 224-231. DOI $10.1159 / 000330117$.

[14] NEMA, G. F., LOCATELLI, J., FREITASAND, P. C., and SILVA, G. L., 2000. Antibacterial activity of plant extracts and phytochemicals on antibiotic-resistant bacteria. Brazilian
Journal of Microbiology 31, 247-256. DOI http://dx.doi.org/10.1590/S1517-83822000000400003.

[15] SOURI, E., AMIN, G., FARSAM, H., JALALIZADEH, H., and BAREZI, S., 2010. Screening of thirteen medicinal plant extracts for antioxidant activity. Iranian Journal of Pharmaceutical Research, 149-154. DOI 10.22037/IJPR.2010.758.

[16] KIM, D.-O., CHUN, O. K., KIM, Y. J., MOON, H.-Y., and LEE, C. Y., 2003. Quantification of polyphenolics and their antioxidant capacity in fresh plums. Journal of Agricultural and Food Chemistry 51, (22), 6509-6515. DOI https://doi.org/10.1021/jf0343074.

[17] TOMÁS-BARBERÁN, F. A., GIL, M. I., CREMIN, P., WATERHOUSE, A. L., HESS-PIERCE, B., and KADER, A. A., 2001. HPLC- DAD- ESIMS analysis of phenolic compounds in nectarines, peaches, and plums. Journal of Agricultural and Food Chemistry 49, (10), 4748-4760. DOI https://doi.org/10.1021/jf0104681.

[18] KIM, Y.-K., KOO, B.-S., GONG, D.-J., LEE, Y.-C., KO, J.-H., and KIM, C.-H., 2003. Comparative effect of Prunus persica L. BATSCH-water extract and tacrine (9-amino-1, 2, 3, 4tetrahydroacridine hydrochloride) on concentration of extracellular acetylcholine in the rat hippocampus. Journal of ethnopharmacology 87, (2-3), 149-154. DOI 10.1016/S03788741(03)00106-5.

[19] MIYAZAWA, M. and HISAMA, M., 2003. Antimutagenic activity of phenylpropanoids from clove (Syzygium aromaticum). Journal of Agricultural and Food Chemistry 51, (22), 6413-6422. DOI https://doi.org/10.1021/jf030247q.

[20] KAMEI, H., KOJIMA, T., HASEGAWA, M., KOIDE, T., UMEDA, T., YUKAWA, T., and TERABE, K., 1995. Suppression of tumor cell growth by anthocyanins in vitro. Cancer Investigation 13, (6), 590-594. DOI https://doi.org/10.3109/07357909509024927.

[21] ABIDI, W., CANTÍN, C. M., JIMÉNEZ, S., GIMÉNEZ, R., MORENO, M. Á., and GOGORCENA, Y., 2015. Influence of antioxidant compounds, total sugars and genetic background on the chilling injury susceptibility of a non-melting peach (Prunus persica (L.) Batsch) progeny. Journal of the Science of Food and Agriculture 95, (2), 351-358. DOI $10.1002 /$ jsfa. 6727.

[22] LOIZZO, M. R., PACETTI, D., LUCCI, P., NÚÑEZ, O., MENICHINI, F., FREGA, N. G., and TUNDIS, R., 2015. Prunus persica var. platycarpa (Tabacchiera Peach): bioactive compounds and antioxidant activity of pulp, peel and seed ethanolic extracts. Plant foods for human nutrition 70, (3), 331-337. DOI 10.1007/s11130-015-0498-1.

[23] WANG, N., QINGYUN, L., DAIYIN, P., LAN, W., and SHENGXIANG, W., 2002. Experimental Study on Antithrombus Effect of Different Extracts from Semen Persicae $[\mathrm{J}]$. Journal of Chinese Medicinal Materials 6 . http://en.cnki.com.cn/Article_en/CJFDTotalZYCA200206017.htm.

[24] XU, L., LIU, P., LIU, C., HONG, J., LU, G., XUE, H., ZHU, J., and HU, Y., 1994. Observation on the action of extractum semen Persicae on anti-fibrosis of liver. Zhongguo Zhong yao za zhi $=$ Zhongguo zhongyao zazhi $=$ China journal of Chinese materia medica 19, (8), 491-494, 512 https://europepmc.org/abstract/med/7980864. 
[25] ARICHI, S., KUBO, M., TANI, T., NAKAMURA, H., IMAZU, C., KADOKAWA, T., NAGAMOTO, N., NANBA, K., and NISHIMURA, H., 1985. Studies on Persicae semen. III. Oxygen radical scavenging activity of PR-B, an antiinflammatory protein of Persicae semen. Yakugaku zasshi: Journal of the Pharmaceutical Society of Japan 105, (9), 895901. DOI 10.1248/yakushi1947.105.9_895.

[26] EDENHARDER, R., KRIEG, H., KÖTTGEN, V., and PLATT, K., 2003. Inhibition of clastogenicity of benzo [a] pyrene and of its trans-7, 8-dihydrodiol in mice in vivo by fruits, vegetables, and flavonoids. Mutation Research/Genetic Toxicology and Environmental Mutagenesis 537, (2), 169-181. DOI 10.1016/S1383-5718(03)00078-0.

[27] ABOUL-ELA, E. I. and OMARA, E. A., 2014. Genotoxic and histopathological aspects of treatment with grape seed extract on cancer induced with cyclophosphamide in mice. J Cell Biol 2, 18-27. DOI 10.11648/j.cb.20140203.11.

[28] CHO, H.-B., PARK, J.-H., SEO, B.-I., CHO, S.-Y., PARK, K.-R., CHOI, S.-H., HAN, C.-K., SONG, C.-H., PARK, S.-J., and KU, S.-K., 2013. Single Oral Dose Toxicity Test of Persicae Semen Aqueous Extracts in Mice. The Korea Journal of Herbology 28, (3), 17-24. $\mathrm{http} / /$ citeseerx.ist.psu.edu/viewdoc/download?doi=10.1.1.885 $.1805 \&$ rep $=$ rep $1 \&$ type $=$ pdf

[29] ATtiA, S. M., AL-ANTEET, A. A., AL-RASHEED, N. M., ALHAIDER, A. A., and AL-HARBI, M. M., 2009. Protection of mouse bone marrow from etoposide-induced genomic damage by dexrazoxane. Cancer Chemotherapy and Pharmacology 64, (4), 837-845. DOI https://doi.org/10.1007/s00280-009-0934-8.

[30] SCHMID, W., 1976. The micronucleus test for cytogenetic analysis. In Chemical mutagens Springer, 31-53. DOI: http://dx.doi.org/DOI https://doi.org/10.1007/978-1-46840892-8 2.

[31] YOSIDA, H. T. and AMANO, K. H., 1965. Autosomal polymorphism in laboratory bred and wild Norway rats, Rattus norvegicus, found in Misima.

[32] FRAISER, L. H., KANEKAL, S., and KEHRER, J. P., 1991. Cyclophosphamide toxicity. Drugs 42, (5), 781-795. DOI 0012-6667/91/0011-0781/\$07.50/0.

[33] DAS, U. B., MALLICK, M., DEBNATH, J. M., and GHOSH, D., 2002. Protective effect of ascorbic acid on cyclophosphamide-induced testicular gametogenic and androgenic disorders in male rats. Asian journal of andrology 4, (3), 201-208. http://www.asiaandro.com/archive/1008682X/4/201.htm?rgwzfkuotmfihfbc?frpegdgdnhojsrio?ywjzyn rgtmpvqezf?fumiotmwjzpeihmy?cesiqqnynrplufri?skbzahydxs bcojsr.

[34] GHOSH, D., DAS, U., GHOSH, S., MALLICK, M., and DEBNATH, J., 2002. Testicular gametogenic and steroidogenic activities in cyclophosphamide treated rat: a correlative study with testicular oxidative stress. Drug and chemical toxicology 25, (3), 281-292. DOI https://doi.org/10.1081/DCT-120005891.

[35] ANDERSON, D., BISHOP, J. B., GARNER, R. C., OSTROSKY-WEGMAN, P., and SELBY, P. B., 1995. Cyclophosphamide: Review of its mutagenicity for an assessment of potential germ cell risks. Mutation Research/Fundamental and Molecular Mechanisms of $\begin{array}{llll}\text { Mutagenesis } & 330, & \text { (1), } & 115-181 \text { DOI }\end{array}$
https://doi.org/10.1016/0027-5107(95)00039-L.

[36] MURATA, M., SUZUKI, T., MIDORIKAWA, K., OIKAWA, S., and KAWANISHI, S., 2004. Oxidative DNA damage induced by a hydroperoxide derivative of cyclophosphamide. Free Radical Biology and Medicine 37, (6), 793-802.

DOi https://doi.org/10.1016/j.freeradbiomed.2004.05.009.

[37] DKHIL, M. A., TOHAMY, A., and GABRY, M. S., 2011. Chromosomal aberrations induced in bone marrow cells of mice due to the administration of the non-steroidal antiinflammatory drug, Piroxicam. African Journal of Pharmacy and Pharmacology 5, (1), 93-103. DOI 10.5897/AJPP10.267.

[38] DOLARA, P., TORRICELLI, F., and ANTONELLI, N., 1994 Cytogenetic effects on human lymphocytes of a mixture of fifteen pesticides commonly used in Italy. Mutation Research Letters 325, (1), 47-51. DOI https://doi.org/10.1016/01657992(94)90026-4.

[39] DE HONDT, H., FAHMY, A., and ABDELBASET, S., 1984. Chromosomal and biochemical studies on the effect of kat extract on laboratory rats. Environmental mutagenesis 6, (6), 851-860. DOI https://doi.org/10.1002/em.2860060611.

[40] ITO, D. and MATSUMOTO, T., 2010. Molecular Mechanisms and Function of the Spindle Checkpoint, a Guardian of the Chromosome Stability. In Polyploidization and Cancer, R. Y. C. POON Ed. Springer New York, New York, NY, 15-26. DOI: http://dx.doi.org/DOI 10.1007/978-14419-6199-0 2.

[41] GOLDBERG, M. T., BLAKEY, D. H., and BRUCE, W. R., 1983. Comparison of the effects of 1, 2-dimethylhydrazine and cyclophosphamide on micronucleus incidence in bone marrow and colon. Mutation Research/Fundamental and Molecular Mechanisms of Mutagenesis 109, (1), 91-98. DOI https://doi.org/10.1016/0027-5107(83)90098-2.

[42] STEVENS, J. F. and MAIER, C. S., 2008. Acrolein: sources, metabolism, and biomolecular interactions relevant to human health and disease. Molecular nutrition \& food research 52, (1), 7-25. DOI https://doi.org/10.1002/mnfr.200700412.

[43] WANG, H.-T., HU, Y., TONG, D., HUANG, J., GU, L., WU, X.-R., CHUNG, F.-L., LI, G.-M., and TANG, M.-S., 2012. Effect of carcinogenic acrolein on DNA repair and mutagenic susceptibility. Journal of Biological Chemistry 287, (15), 12379-12386. DOI 10.1074/jbc.M111.329623.

[44] SENTHILKUMAR, S., YOGEETA, S. K., SUBASHINI, R., and DEVAKI, T., 2006. Attenuation of cyclophosphamide induced toxicity by squalene in experimental rats. Chemicobiological interactions 160, (3), 252-260. DOI 10.1016/j.cbi.2006.02.004

[45] OHNO, Y. and ORMSTAD, K., 1985. Formation, toxicity and inactivation of acrolein during biotransformation of cyclophosphamide as studied in freshly isolated cells from rat liver and kidney. Archives of toxicology 57, (2), 99-103. DOI https://doi.org/10.1007/BF00343118.

[46] YOUSEFIPOUR, Z., RANGANNA, K., NEWAZ, M., and MILTON, S., 2005. Mechanism of acrolein-induced vascular toxicity. Journal of physiology and pharmacology 56, (3), 337. http://www.jpp.krakow.pl/journal/archive/09 05/pdf/337 09 05_article.pdf. 
[47] ABDELFATTAH-HASSAN, A., SHALABY, S. I., KHATER, S. I., EL-SHETRY, E. S., ABD EL FADIL, H., and ELSAYED, S. A., 2019. Panax ginseng is superior to vitamin $\mathrm{E}$ as a hepatoprotector against cyclophosphamide-induced liver damage. Complementary Therapies in Medicine 46, 95102. DOI https://doi.org/10.1016/j.ctim.2019.08.005.

[48] FOUAD, A. A., QUTUB, H. O., and AL-MELHIM, W. N., 2016. Punicalagin alleviates hepatotoxicity in rats challenged with cyclophosphamide. Environmental Toxicology and $\begin{array}{llll}\text { Pharmacology } & 45, & 158-162 . & \text { DOI }\end{array}$ https://doi.org/10.1016/j.etap.2016.05.031.

[49] CUCE, G., ÇETINKAYA, S., KOC, T., ESEN, H. H., LIMANDAL, C., BALC1, T., KALKAN, S., and AKOZ, M., 2015. Chemoprotective effect of vitamin $\mathrm{E}$ in cyclophosphamide-induced hepatotoxicity in rats. Chemicobiological interactions 232, 7-11. DOI https://doi.org/10.1016/j.cbi.2015.02.016.

[50] ALQAHTANI, S. and MAHMOUD, A. M., 2016. GammaGlutamylcysteine ethyl Ester protects against cyclophosphamide-induced liver injury and hematologic alterations via upregulation of PPAR $\gamma$ and attenuation of oxidative stress, inflammation, and apoptosis. Oxidative medicine and cellular longevity 2016. DOI http://dx.doi.org/10.1155/2016/4016209.

[51] OYAGBEMI, A. A., OMOBOWALE, O. T., ASENUGA, E. R., AKINLEYE, A. S., OGUNSANWO, R. O., and SABA, A. B., 2016. Cyclophosphamide-induced hepatotoxicity in wistar rats: the modulatory role of gallic acid as a hepatoprotective and chemopreventive phytochemical. International journal of preventive medicine 7. DOI 10.4103/2008-7802.177898.

[52] BHAT, N., KALTHUR, S. G., PADMASHALI, S., and MONAPPA, V., 2018. Toxic Effects of Different Doses of Cyclophosphamide on Live. Ethiopian journal of health $\begin{array}{lll}\text { sciences } & 28, & (6) .\end{array}$ http://dx.doi.org/10.4314/ejhs.v28i6.5.

[53] ADIKWU, E. and BOKOLO, B., 2018. Effect of cimetidine on cyclophosphamide-induced liver toxicity in albino rats. Asian Journal of Medical Sciences 9, (5), 50-56. DOI http://orcid.org/0000-0001-6426-6228.

[54] COHEN, S. M., GARLAND, E. M., JOHN, M. S., OKAMURA, T., and SMITH, R. A., 1992. Acrolein initiates rat urinary bladder carcinogenesis. Cancer Research 52, (13), 3577-3581. https://cancerres.aacrjournals.org/content/52/13/3577.full-text.pdf.

[55] YOKOYAMA, Y., FUTAGAMI, M., FUKUSHI, Y., SAKAMOTO, T., HIGUCHI, T., FUJII, S., SATO, S., TAKAMI, H., and SAITO, Y., 2000. Secondary acute nonlymphocytic leukemia following successful chemotherapy combining cisplatin, doxorubicin, and cyclophosphamide for stage IV epithelial ovarian cancer. Archives of Gynecology and Obstetrics 263, (4), 206-207. DOI https://doi.org/10.1007/s004040050285.

[56] HELLER, A., TRIFONOV, V., RUBTSOV, N., SAUERBREY, A., STARKE, H., LONCAREVIC, I. F., CLAUSSEN, U., and LIEHR, T., 2003. Complex chromosomal rearrangements in a secondary acute myeloblastic leukemia after chemotherapy in TRAPS. Oncology reports 10, (6), 1789-1792. DOI https://doi.org/10.3892/or.10.6.1789.

[57] BLOCK, G., PATTERSON, B., and SUBAR, A., 1992. Fruit, vegetables, and cancer prevention: a review of the epidemiological evidence. Nutrition and cancer 18, (1), 1-29. DOI 10.1080/01635589209514201.

[58] GARCíA-ALONSO, M. A., DE PASCUAL-TERESA, S., SANTOS-BUELGA, C., and RIVAS-GONZALO, J. C., 2004. Evaluation of the antioxidant properties of fruits. Food Chemistry 84, (1), 13-18. DOI 10.1016/S0308-8146(03)00160-2.

[59] CAMPBELL, O. E. and PADILLA-ZAKOUR, O. I., 2013. Phenolic and carotenoid composition of canned peaches (Prunus persica) and apricots (Prunus armeniaca) as affected by variety and peeling. Food research international 54, (1), 448-455. DOI https://doi.org/10.1016/j.foodres.2013.07.016.

[60] EDENHARDER, R., FRANGART, J., HAGER, M., HOFMANN, P., and RAUSCHER, R., 1998. Protective Effects of Fruits and Vegetables against In Vivo Clastogenicity of Cyclophosphamide or Benzo [a] pyrene in Mice. Food and Chemical Toxicology 36, (8), 637-645. DOI https://doi.org/10.1016/S0278-6915(98)00035-0.

[61] GHOBADI POUR, M., MIRAZI, N., and SEIF, A., 2019. Treatment of liver and spleen illnesses by herbs: Recommendations of Avicenna's heritage "Canon of Medicine". Avicenna journal of phytomedicine 9, (2), 101-116. https://www.ncbi.nlm.nih.gov/pmc/articles/PMC6448543/.

[62] SAOUDI, S., KHENNOUF, S., MAYOUF, N., AMIRA, S., and DAHAMNA, S., 2019. Evaluation of the in vivo and in vitro antioxidant capacity and phytochemical Screening of phenolic compounds of Fargaria ananassa, Prunus armeniaca and Prunus persica fruits growing in Algeria. Progress in Nutrition 22, (1). DOI https://doi.org/10.23751/pn.v22i1.8011.

[63] NORATTO, G., PORTER, W., BYRNE, D., and CISNEROSZEVALLOS, L., 2014. Polyphenolics from peach (Prunus persica var. Rich Lady) inhibit tumor growth and metastasis of MDA-MB-435 breast cancer cells in vivo. The Journal of nutritional biochemistry 25, (7), 796-800. DOI https://doi.org/10.1016/j.jnutbio.2014.03.001.

[64] BARCELOUX, D. G., 2008. Medical toxicology of natural substances: foods, fungi, medicinal herbs, plants, and venomous animals. John Wiley \& Sons.

[65] NORATTO, G., PORTER, W., BYRNE, D., and CISNEROSZEVALLOS, L., 2009. Identifying Peach and Plum Polyphenols with Chemopreventive Potential against Estrogen-Independent Breast Cancer Cells. Journal of Agricultural and Food Chemistry 57, (12), 5219-5226. DOI https://doi.org/10.1021/jf900259m.

[66] HEO, M. Y., KIM, S. H., YANG, H. E., LEE, S. H., JO, B. K., and KIM, H. P., 2001. Protection against ultraviolet B-and Cinduced DNA damage and skin carcinogenesis by the flowers of Prunus persica extract. Mutation Research/Genetic Toxicology and Environmental Mutagenesis 496, (1-2), 47-59. DOI https://doi.org/10.1016/S1383-5718(01)0218-2.

[67] LEE, C. K., PARK, K.-K., HWANG, J.-K., LEE, S. K., and CHUNG, W.-Y., 2008. The pericarp extract of Prunus persica attenuates chemotherapy-induced acute nephrotoxicity and hepatotoxicity in mice. Journal of medicinal food 11, (2), 302306. DOI https://doi.org/10.1089/jmf.2007.545.

[68] XI, S., SHI, M., JIANG, X., MINUK, G. Y., CHENG, Y., PENG, Y., GONG, Y., XU, Y., WANG, X., and YANG, J., 2016. The effects of Tao-Hong-Si-Wu on hepatic necroinflammatory activity and fibrosis in a murine model of chronic liver disease. Journal of ethnopharmacology 180, 2836. DOI https://doi.org/10.1016/j.jep.2016.01.030. 
[69] ZHANG, Y., LUO, J.-X., HU, X.-Y., YANG, F., ZHONG, S., and LIN, W., 2016. Improved prescription of taohechengqitang alleviates D-galactosamine acute liver failure in rats. World journal of gastroenterology 22, (8), 2558. DOI 10.3748/wjg.v22.i8.2558.

[70] ZHAO, X., LIAO, Z., QI, Y., SHEN, X., BI, K., and JIA, Y., 2016. Antioxidative activity of methyl amygdalinate from the seeds of Prunus persica and neuroprotective effects on $A \beta 1-$ 42-induced neurodegeneration models. RSC Advances 6, (96), 93794-93800. DOI 10.1039/C6RA18913J.
[71] KIM, S.-R., LEE, J.-W., LIM, S.-Y., JUNG, Y.-S., CHOI, H.Y., and KIM, J.-D., 2012. Rat single oral dose toxicity test of Armeniacae Semen (including endocarp). The Journal of Internal Korean Medicine 33, (2), 145-159. https://www.jikm.or.kr/journal/view.php?number=1650. 